ample, glycyrrhizin from the roots of the liquorice plant, the fruit of the South Chinese Lo Han Kuo and the leaves of the Paraguayan shrub Stevia rebaudiana. Stevioside, a triterpene glycoside, which is readily extracted from the leaves of $S$. rebaudiana, is being produced on a commercial scale in Japan by the Toyo Menka Karisha Company. Stevioside, which is approximately 300 times sweeter than sucrose, is not a permitted food additive elsewhere.

More recently the serendipity berry (Dioscoreophyllum cumminsii) was identified in a broad survey of sweet fruits undertaken by George Inglett and J. F. May, Department of Agriculture, in 1968. Its berries are intensely sweet owing to the presence of the protein monellin which is approximately 2,000 times as sweet as sucrose. A similar protein, thaumatin, has been isolated from the fruit of a West African plant Thaumatococcus daniellii by $H$. van der Wel and $K$. Loeve of Unilever. This has proved to be the sweetest substance known, being around 4,000 times sweeter than sucrose. The extraction, purification and properties of both monellin and thaumatin have been studied extensively, in particular by Tate \& Lyle, who are able to produce thaumatin in kilogramme quantities. However, the toxicology of thaumatin has not been fully evaluated, though, being a vegetable protein which has been consumed for generations, it seems unlikely that it would have harmful side-effects.

Similar considerations would seem to apply miraculin, the glycoprotein extracted from the berries of the bush Synsepalum dulcificum, also native to West Africa. An extract of this fruit, which has the property of tasting intensely sweet only in the presence of acids, was marketed for a time by the Miralin Corporation of America who established extensive plantations in several countries to produce the extract. However, FDA approval for this product was denied in 1974 pending toxicology testing, with the consequence that it is not now commercially available.
Naturally occurring sugars and sugar alcohols, such as fructose, xylitol and maltitol, are also being evaluated as alternative sweeteners, though since they are metabolised, they cannot be regarded as non-calorific. Xylitol, produced from birch wood, is available at ten times the price of sugar. It is finding use as a sweetener in chewing gum, though it is not a permitted sweetener in Britain and, following recent evidence of potential carcinogenic activity, may be prohibited in the US.

In spite of the intense interest worldwide in developing alternative sweeteners, the ideal non-nutritive sweetener -water soluble, chemically and thermally stable, of pure flavour, nontoxic, and of high sweetness intensityhas not yet been discovered and may still be some years off. In the meantime a less satisfactory compromise seems incvitable.

K. J. Parker is General Manager, Research, with Tate \& Lyle Limited.

\section{No soft options in Carter's energy research policy}

ENERGY policy was a major plank in Jimmy Carter's campaign platform during the 1976 Presidential election. In a year when the rising cost of imported oil was causing increasing economic concern, and the late E. F. Schumacher was telling capacity audiences that "Small is beautiful", Carter promised that, if elected, he would shift the emphasis of US energy technology away from a prime dependence on nuclear fuels and towards non-nuclear alternatives, in particular renewable resources such as solar power.

But like many other campaign promises--for example that to reduce the budget of the Defense Department, now scheduled for a 9.4 per cent increase to $\$ 117.8$ billion in fiscal year 1979-Carter's energy plans have, in the face of established institutional positions and interests, undergone considerable revision in his first year of office.

The President has maintained his firm stand on the dangers of proliferation resulting from the production of plutonium by fast breeder reactors, in particular demanding the closure of the Clinch River liquid metal fast breeder reactor at Oak Ridge, Tennessee.

But the administration is still pursuing a vigorous nuclear policy through other options, including possibly a major design project for a thorium- cycle reactor. And already last year, following, in particular, moves to speed up the licensing of new reactors, Carter's earlier claims that he would turn to nuclear energy only as "a last resort" were beginning to wear thin.

Further confirmation that energy policy has changed little comes from analysis of the Department of Energy's proposed research and development budget for the fiscal year 1979. In presenting this to Congress two weeks ago, President Carter has suggested that the overall level of energy $R \& D$ remain roughly static at $\$ 2.7$ billion.

The budget contains considerable increases in commitments to research on synthetic fuels (another area in which campaign promises seem to have been forgotten). In contrast, resources for research into renewable energy sources show little change. It is proposed, for example, to raise the budget for windpower research from $\$ 37$ million to $\$ 41$ million; and solar power research, which has grown from $\$ 4$ million in 1974 to $\$ 193$ million in 1977 and \$303 million last year, will increase only to $\$ 309$ million. The increases in these two topics scarcely keep up with the expected increase in the cost of living.

There are, admittedly, some important shifts in philosophy reflected in the budget proposals. Perhaps the

\section{Sorry, for copyright reasons some images on this page may not be available online}

The inauguration of the US

National Aeronautics and Space Administration's windmill in New Mexico 
most significant is a hefty $27 \%$ increase in funds for conservation R\&D, under which funds for research on topics such as motor efficiency and energy storage will be increased from $\$ 301$ to $\$ 381$ million.

In addition, the proposed closure of the Clinch River fast breeder project, the subject of a furious political battle last autumn, after which Carter vetoed the authorisation bill and is yet to decide what to do with a supplemental appropriation of $\$ 80$ million passed by Congress, would save $\$ 150$ million, creating an apparent swing in emphasis from nuclear to non-nuclear technology.

But apart from the Clinch River project, there has been little change in relative priorities. Indeed if the Clinch River funds are extracted from the 1978 budget figures, the proportion of R\&D expenditure going to other nuclear projects actually increases between 1978 and 1979 , from 45.8 to 46.4 per cent of the total for research and technology development.

There is therefore still a strong continuation of pre-Carter policy directions. Dr John Deutch, who recently moved from chairman of the department of chemistry at the Massachusetts Institute of Technology to become director of the Office of Energy Research, told a House Subcommittee last week that "the strategic approach to our nation's energy R\&D efforts has been evolving over the last several years".

But if there has been no obvious shift in priorities, there has been a significant change in strategy. In presenting the President's proposed R\&D budget two weeks ago, Dr Frank Press, director of the Office of Science and Technology Policy, said that the administration was trying to shift the emphasis of R\&D funding away from development projects--considered the responsibility of private industrytowards more basic research.

Dr Deutch shares this strategy, although he puts it slightly differently. In an interview with Nature last week he pinpointed the problem in energy research as lying not at the level of basic science, in which the department's position is relatively strong, but at an intermediate point in the $R \& D$ spectrum which he identifies as "advanced development work". In this he includes fields such as geology, and chemical and process engineering.

Dr Deutch also stresses the need to maintain flexibility in research programmes, developing a "hedged" strategy and keeping options open, so that the department can respond quickly both to new research potentials, and to changing parameters affecting energy supply.

In the nuclear field, for example, one criticism of the Clinch River project has been that its massive funding has required putting too many eggs into one basket, and that the project was an attempt to move too fast in a single direction when revised predictions of future energy demand are indicating that the speed may be premature.

In contrast, the administration is suggesting that a close look should be taken at a wide range of options in the nuclear field, and at an earlier stage than project development. Thus within an overall R\&D budget that is virtually static, funding for "basic energy sciences" is being increased by 20 per cent from $\$ 177$ million to $\$ 212$ million, and for nuclear research and applications by 22 per cent from $\$ 227$ to $\$ 278$ million. "Advanced technology and assessment projects', which will involve a mechanism for monitoring and providing a critique of $R \& D$ programmes, will be increased almost three-fold, from $\$ 8$ million to $\$ 21$ million.

One alternative that President Carter is known to be particularly enthusiastic about is the thorium cycle reactor which, by using the thorium-uranium conversion process rather than the uranium-plutonium process, would be much safer than the conventional fast breeder.

Carter's enthusiasm for the thorium cycle is not shared by the environmentalist lobby, many of whom feel that it still fails to meet adequate safety criteria, at least in comparison with once-through light water reactors. But the Department of Engery is expected to announce soon a major $\$ 15$ million project for the conceptual design of a 650 to 900 megawatt reactor, to fill the programme gap left by terminating the Clinch River project; and the thorium cycle is a high contender for this new design.

Dr Deutch said last week that he felt

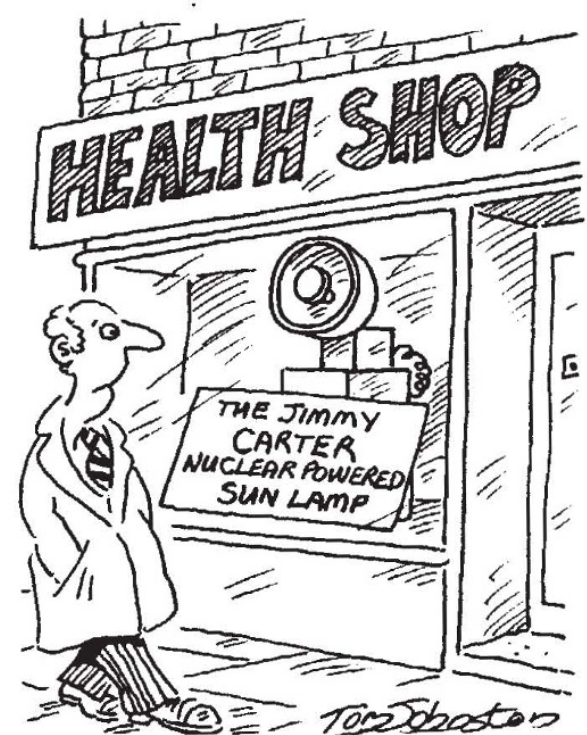

there was still not sufficient stress on solar research and development. But in line with the administration's general approach to R\&D, funds for "production, demonstration and distribution" of solar energy supply are being reduced from $\$ 87$ million to $\$ 64$ million in 1979.

The decision to limit the growth of solar research funds has not been a popular one in Congress, where solar energy, with its apparent promise as a pollution-free, virtually infinite resource, carries a strong and populist appeal. Pointing out in the House of Representatives that the cuthacks in the solar energy programme were more than the salary increases requested by the Department of Energy, Representative Louis Frey $\mathrm{J}_{\mathrm{r}}$ of Florida claimed that the budget could be characterised as "one giant step backward in energy research and development."

There will be a powerful campaign to increase solar energy's share of the $R \& D$ budget when the latter is debated in committee. And the campaign will receive added fuel from a shortlyexpected report from Congress' General Accounting Office, which is thought to suggest that as much as $\$ 600$ million-almost twice the amount proposed by the administration--could be fruitfully absorbed into existing and proposed solar energy research projects.

In itself, the apparent conflict between the administration and Congress is not too important. In areas known to have enthusiastic support on Capitol Hill, the administration is often claimed to feel safe in going for a low budget knowing that it will be increased, and that it can put in higher bids in areas which Congress traditionally cuts back.

But in this case the stakes are higher than usual. President Carter has publicly asked to be judged by the success of his energy policy; hence his frustration at the stalemate on energy legislation, and the important symbolic role that it has taken on. However, in cutting back on solar energy research and continuing to emphasise nuclear options, whatever the administrative and scientific logic, he stands to lose the confidence of precisely those whose support he needs to push through his whole cnergy policy.

As one environmentalist who has been closely involved with recent debates said last week, in words that have been echoed across a range of issues: 'I'm obviously disappointed that Carter's going back on his campaign promises, but l'm more disappointed that he won't admit what he's doing, that he won't come out and say that he has changed his mind."

David Dickson 